\title{
Visioning Business Model Innovation for Emerging 5G Mobile Communications Networks
}

\author{
Sara Moqaddamerad
}

\author{
(l In a world of uncertainty, our guiding philosophy is: Take charge. If nobody knows \\ what the future will hold, your vision of how to navigate it is as good as anyone's. \\ The future may as well belong to you. "' \\ Rita Gunther McGrath \\ Professor of Management \\ Columbia Business School
}

\begin{abstract}
The purpose of this research is to introduce and apply a novel approach for developing business model innovation. It shows step-by-step how to envision and create business model innovation activities. The data was collected through a case study of a European provider of technical services in the electricity and telecommunications network industry, which is coping with the uncertainty and complexity of emerging fifth generation mobile communications networks (5G) and subsequently the transformation of telecom markets. This paper contributes to the intersection of strategic foresight and business model innovation by synthesizing existing knowledge and in-depth case evidence to demonstrate how business model innovation is developed in the context of emerging disruptive technologies using future-oriented methods.
\end{abstract}

\section{Introduction}

With the emergence of the next generation of mobile communications technology, known as " $5 \mathrm{G}$ ", the telecommunications industry faces a major disruption and transformation. 5G technology aims to interconnect people globally and create real-world wireless and networked societies (Mitra \& Agrawal, 2015). These disruptive signals of change are already creating a new level of uncertainty and turbulence that demands agility (Gibson, 2014) and business model innovation (BMI), so that enterprises can offer new products, services and revenue models, which can be created and captured by existing and new players (Chesbrough \& Rosenbloom, 2002; CasadesusMasanell \& Zhu, 2013; Wieland et al., 2017).

Business models are important for commercializing and creating economic value from (new) technologies (Chesbrough, 2010). They are one of the foremost tools for innovation, involving both competition and describing the position of a firm within its value network (Chesbrough, 2010; Casadesus-Masanell \& Ricart, 2010; Demil \& Lecocq, 2010; Zott et al., 2011; Casadesus-Masanell \& Zhu, 2013; Lanzolla \& Markides,
2020). BMI extends the business model and is crucial in creating and capturing value from technology-driven changes (Casadesus-Masanell et al., 2010; Wieland et al., 2017). As a result, the strategic innovation of business models substantially impacts the long-term prospects of a firm in today's dynamic environment (Wirtz et al., 2010). BMI offers a way to cope with a new form of organizing a business in an efficient and effective way that can lead to sustainable competitive advantage (Wirtz \& Daiser, 2018).

Even though, BMI is widely acknowledged as a potential response to disruption and changes in the sources of value creation, it remains one of the most challenging tasks for managers (Eppler \& Hoffmann, 2012). This is due to environmental volatility, uncertainty, complexity, and ambiguity (VUCA), as well as shifts in competition, new regulations for markets and governments that have been increasing by fast-paced technological changes. These changes have compelled some firms to rethink and enhance their BMI continuously (Schaller \& Vatananan-Thesenvitz, 2018). The other challenge is a lack of concrete guidance on how a company can innovate its business model (Bucherer et al., 2012; Schaller \& Vatananan-Thesenvitz, 2018), along with few 


\section{Visioning Business Model Innovation for Emerging 5G Mobile Communications Networks Sara Moqaddamerad}

possibilities for assessing BMI in abstract fashion, which means that BMI requires experimentation and stabilization time (Teece, 2010).

Moreover, academic work on BMI to a great extent has been developed in silos (Zott et al., 2011), conceptual and empirical studies on BMI are few (Gibson, 2014), and the wide application of BMI in various fields makes it highly diversified (Massa et al., 2017). Schneider and Spieth (2013) argued that existing studies point towards continued exploration of BMI in further contexts to enhance our understanding of how to support firms (in terms of tools and methods) throughout the BMI process. Moreover, established processes related to BMI, apparently are not common in practice (Cortimiglia, et al. 2015), since BMI is often seen as an ad hoc (rather than systematic) process, without a clear framework for exploring opportunities (Girotra \& Netessine, 2014). Although, Wirtz and Daiser (2018) detected seven generic BMI process steps (analysis, ideation, feasibility, prototyping, decisionmaking, implementation, and sustainability), they underscored the still heterogeneous (in content and scope) structure of BMI process knowledge within the literature.

Little theoretical understanding exists concerning how business model tools work and enable BMI. The term "BMI tool" is still rather ambiguous in the literature and has taken numerous forms, understood broadly as techniques, methods, approaches, and frameworks built to support various tasks in different stages of BMI. They are mostly created conceptually and have not yet been applied and evaluated systematically (Schwarz \& Legner, 2020). The existing frameworks that integrate tools and methods are still quite generic, which makes decision-making during innovation processes rather difficult (Girotra \& Netessine, 2014; Tesch \& Brillinger, 2017).

These difficulties indicate that we still have a limited and disparate understanding of BMI (processes and methods). With this in mind, I was motivated to study BMI in a new context to help create a new way for developing BMI. Thus, I began to integrate elements from an activity system perspective on BMI (Amit \& Zott, 2012) together with a BMI process model developed by Wirtz and Daiser (2018). This suggested a new approach was needed involving strategic foresight, a way of creating high-quality functional forward-thinking views to make informed decisions in the present (Karp, 2004). This was believed could support firms wishing to explore BMI in environments characterized by VUCA. The research, therefore, also answers the call for further research about "the process and elements of BMI as well as its enablers and effects in anticipation and response to increasing environmental volatility", made by Foss and Saebi (2017).

The application of strategic foresight for developing BMI in the context of innovative technologies is not yet prevailing in the literature. This paper contributes to this gap both in theory and practice, by providing insights from utilizing two strategic foresight methods, that is, "horizon scanning" and "visioning" during the process of creating new business models in the context of $5 \mathrm{G}$ networks. Herein the main research question driving this study is:

\section{How can future-oriented business model innovation be developed for emerging disruptive technologies?}

The structure of the paper is as follows. First, a review of existing literature on the concepts of business model and BMI from a strategic perspective. Following this, a discussion about strategic foresight to provide the background for practicing a new approach of BMI. After that, the research design and method present an overview of the empirical research context and strategic foresight methods employed in the process of BMI. Next, a discussion of the research findings, and finally, conclusions and implications for management theory and practice.

\section{Summary of Key Insights from the Literature}

\subsection{Understanding business models and business model innovation}

Business model and strategy

The origin of business modelling goes back to value creation and capture within the internet business in the mid-1990s. It has been gaining momentum since then and has become a key concept for technology, innovation, management, and strategy fields (Afuah \& Tucci, 2001; Amit \& Zott, 2001; Zott et. al., 2011). The definition of 'business model' has been prolific since its birth. For instance, Osterwalder et al. (2005) defines a business model as a conceptual tool that consists of a set of concepts and their relationships that reflects the business logic of a specific firm, describes the value provided for customers, and how that value is created and monetized. Business models have also been studied 


\section{Visioning Business Model Innovation for Emerging 5G Mobile Communications Networks Sara Moqaddamerad}

on an intuitive and holistic level (as a unit of analysis), describing how firms do business or function to achieve their goals (profitability, growth, etc.) (Massa et al., 2017). Although, there is still no generally accepted definition for all business models due to various uses in the literature (Zott et. al., 2011; Massa et al., 2017), a field that researches business models has gradually developed (Wirtz et al., 2016).

In the "strategy" stream of research, a business model is conceptualized as a structured and analytical model that depicts a business' architecture and links the firm's strategy (how to compete) to its activities (execution of strategy). Accordingly, a business model bridges the formulation and implementation of strategy (Porter \& Gibbs, 2001; Margretta, 2002; Richardson, 2005). Along the same lines, CasadesusMasanell and Ricart (2010) viewed the business model as a direct result of strategy and means for (operative) implementation of market strategies.

Adopting the strategic view, a business model is important to enable a company's plans to create and capture value that spans the internal/external boundaries of the firm and its industry (Amit \& Zott, 2001; Zott \& Amit, 2010). Business model activities (for example, value-chain activities, customer segments, choice of products, services, and revenue mechanisms) involve human, physical and/or capital resources that link value creation with value capture to exploit business opportunities for the parties involved (Chesbrough \& Rosenbloom, 2002; Zott \& Amit, 2010).

Embedded in theoretical and empirical research, Amit and Zott (2001) and Zott and Amit (2010) further explored activity system design as consisting of two parameters: 1) design elements describing the architecture of an activity, including its content, structure, and governance, and 2) design themes describing the sources of the activity system's value creation. The latter includes the novelty that captures the degree of an activity system's innovativeness, the lock-in activities that cause "switching costs" or increased motivation for business model participants to stay within the activity system and transact, complementarities wherein the business model's interdependent activities have value-enhancing effect, and efficiency where the aim is to reduce/save costs through activity system interlinkages. Moreover, these value drivers are often mutually reinforcing, that is, the existence of each value driver can strengthen the effectiveness of any other one (Amit \& Zott, 2001). For instance, collaboration between value drivers provides more effectiveness or complementarities that bring benefit when supported by novel design (Amit \& Zott, 2010).

Interestingly, strategies are also looked at as a system of interrelated activities, as brought to the fore by Porter (1996), who contended that coordinated activities can drive competitive advantage. Thus, a firm's strategy integrates its business model activities, which form the business' value logic (Osterwalder et al., 2005; Zott \& Amit, 2010; Wirtz et al., 2016).

\section{Business model innovation and strategy}

Afuah (2014) defined BMI as a framework for creating and capturing value by doing things differently from the norm (Afuah, 2014). Amit and Zott (2010) suggested BMI means developing a right business model for a specific situation, that is, BMI can occur through value drivers in business models that entail new activities (content), linking activities in a novel way (structure), or altering the activity performed by a particular party in a way that leads to novel forms of cooperation (governance). Changing one or more of these design elements leads to changing the whole model. Thus, BMI denotes designing and implementing an enterprise activity system that is either new to the focal firm, target market, industry, or generally to the world (Amit \& Zott, 2012).

An innovative business model can generate a new market or enable a company to create and exploit new opportunities in an established market (Amit \& Zott, 2010). In a rapidly changing technology market, product innovations without BMI may not always create sufficient competitive advantage (Amit \& Zott, 2010). As a result, BMI designs a process through which a firm may adjust its business model to suit a new competitive landscape (Kindström \& kowalkowski, 2015). Efficient and continuous BMI thus becomes vitally important for maintaining sustainable competitive advantage (Teece, 2010; Cortimiglia et al., 2015).

BMI can be driven by new customer demands, such as the emergence of new value propositions or technology obsolescence (see Casadesus-Masanell \& Ricart, 2010), and also derive from strategic activities, as strategy defines the pattern of BMI (Cortimiglia et al., 2015). Furthermore, BMI can have a positive effect on a firm's strategic flexibility (Schneider \& Spieth, 2013). It requires managers to constantly monitor and identify 


\section{Visioning Business Model Innovation for Emerging 5G Mobile Communications Networks Sara Moqaddamerad}

uncertainties that impact the current business model, anticipate possible consequences of internal and external changes to the firm, and proactively move towards innovating the business model to respond to external changes (Schneider \& Spieth, 2013; Cortimiglia et al., 2015).

Methods like scenario planning and making roadmaps can be used to draw up an innovated business model's specificities. This can lead to identifying a range of new market opportunities based on available key activities, resources, and market attributes. However, there is no specific business model development that need be practiced at that point (Cortimiglia et al., 2015). There have been a couple of notable exceptions: 1) a study done by Tesch (2016), which applied scenario planning to evaluate BMI in the context of digitalization and IoT, and 2) a study done by Moqaddamerad and colleagues (2017) that focused on applying scenario planning to create novel business models in the context of $5 \mathrm{G}$ networks. The following section discusses further the value and importance of such forward-looking methods for BMI.

\subsection{Strategic foresight: a novel approach for the development of business model innovation}

The concept of 'foresight' means to have "an accurate view of the future" (Courtney, 2001). Foresight prepares decision-makers to fulfil future requirements and grasp opportunities, leading them to make more informed decision in the present (Karp, 2004). Strategic foresight enables future competitive advantage and involves "identifying, observing and interpreting factors that induce change, determining possible organization-specific implications, and triggering appropriate organizational responses (Rohrbeck et al., 2015).

Most strategy tools (such as SWOT analysis, and the Five Forces framework) do not encapsulate the dynamic model of reality. This is because they were designed for yesterday's more stable environments, thus adding little foresight on the strategies to win in a tumultuous marketplace (Courtney, 2001; Teece, 2007). Foresight does not emerge from meticulous market analysis or by examining perfect forecasting tools (if they ever existed) (Courtney, 2001). To develop foresight, organizations need to understand and explore the uncertainties they are facing (Karp, 2004) in order to help them find methods and procedures for gaining insight and making informed speculations about the path ahead (Teece, 2007).

Strategic foresight can thus guide the renewal of business models and help cope with the increasing uncertainty and ambiguity of technological and market disruption in two ways. First, it can enable decisionmakers to recognize environmental discontinuities as well as developing ideas to work on emerging technologies, and second, it can provide a set of methods and techniques for selecting the external drivers of change, anticipating their possible development trajectory, detecting their consequences on the organization, and finally formulating the most proper response (Rasmussen et al., 2010; Vecchiato, 2012a \& 2012b). Hence, such a business tool can generate anticipatory and actionable knowledge to be used by decision-makers.

Finally, strategic foresight is important not only to the survival of the firm, but to whole industry. It plays a significant role in strategic planning and innovation, gaining or losing competitive advantage, foreseeing and missing new markets, and making new strategic choices in turbulent circumstances (Lemos \& Porto, 1998). Strategic foresight has arguably the strongest effect when embedded in companies as an ongoing daily practice, and should not be limited only to top management or a specialized $R \& D$ division, but rather also include bottom-up ideation perspectives (Verganti \& Shani, 2016; Sarpong \& Maclean, 2016). The next section presents a systematic way of developing business model innovation using strategic foresight methods.

\section{Research Design and Method}

\section{Research context}

5G telecommunications networks currently constitute a foundation for future digitalized societies based on the timely availability of high-quality wireless connectivity. This suggests changes to the industry's structure such that the traditional mobile telecommunications business dominated by mobile network operators (MNOs) has had to start transforming and becoming more open to new entrants known as local service providers. This transformation has sped up digitalization for local service delivery as well as boosting local businesses into new growth areas. Small operators have promised to provide: 1) hosted local connectivity for MNOs in specific locations, 2) locally tailored content and services, and 3) secure network operation (Matinmikko 


\section{Visioning Business Model Innovation for Emerging 5G Mobile Communications Networks Sara Moqaddamerad}

et al., 2017). However, local operators still need viable business models to achieve innovation, advantage and growth in a high-velocity business environment. Given the paucity of existing research on future $5 \mathrm{G}$ business models, this research aimed to conduct an explorative qualitative single case study to study a contemporary phenomenon within its real-life context (Yin, 2018: 50).

\section{Description of the case company}

The company under study is a leading northern European supplier of technical services for power and communication networks. Founded in 2001, the company operates in Nordic countries as well as Germany, Poland, and Lithuania, with headquarters in Sweden. The company delivers a comprehensive range of solutions that includes designing, planning, building, installing, and securing or maintaining the operation of electrical networks (smart grids, fibre) and (mobile and fixed) telecommunications networks. It also designs and installs charging points for electric cars and internal networks for mobile phone coverage. The company has 6,200 employees out of which 1,500 are based in Finland and its net sales were EUR 1.1 billion in 2019.

\section{Data collection process}

Data was collected from a national project in the telecommunications industry with 5G technology, where the case company was part of the project consortium. The data was collected through: 1) the company's website and professional media (secondary data), 2) ten interviews for selecting and ensuring the diversity of workshop participants, understanding the company's current challenges, as well as scoping and framing strategic foresight activities (Table 1), 3) two consecutive workshops that were designed and facilitated based on the results of the interviews. The first workshop aimed at scoping and opening the context of 5G technological development (for example, opportunities, challenges, possible solutions), analysing the company's current business model, and scanning trends in the telecommunications industry. The second workshop aimed to develop alternative visionary and innovative business models for three years ahead specifically to address the participating company's challenges. Figure 1 shows the process of data collection.

\section{Applying strategic foresight methods: horizon scanning and visioning}

"Horizon scanning", also known as environmental scanning, is usually conducted at the beginning of any strategic foresight activity. Horizon scanning helps to achieve a broad forward-looking view to prepare an organization for change. It entails sensemaking and prioritizing activities and serves as an early warning system to detect emerging indications of important future developments. Additionally, it aids a company in taking timely action well before imminent changes can become problems (Day \& Schoemaker, 2005).

To frame the scope of horizon scanning activities, the author conducted a focused scan to identify new

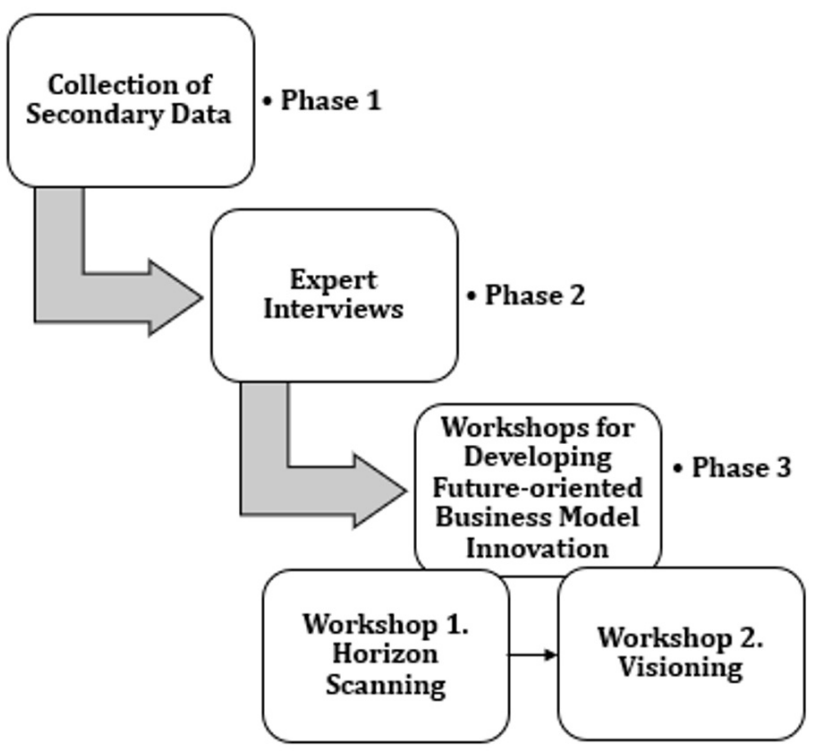

Figure 1. The process of data collection 


\section{Visioning Business Model Innovation for Emerging 5G Mobile Communications Networks Sara Moqaddamerad}

Table 1. Workshop participants and company's challenges

\begin{tabular}{ll}
\hline \multicolumn{1}{c}{ Participants } & Company's challenges and uncertainties \\
\hline 1. Head of digital transformation & - Profitability and growth \\
2. Product manager & - Short-, medium- and long-term visions on 5G \\
3. Mobile communications & - Changing revenue model and service \\
engineer & offerings \\
4. Solution manager & - Company position in the new value chain. \\
5. Area business unit director & - Strengthening sales and marketing activities \\
6. Sales and business development & - Identifying new customers and partners. \\
director & - Investments in new areas and technologies \\
7. Mergers and acquisitions & - Market fragmentation and uncertainty \\
manager & caused by 5G \\
8. Electrical and & - Creating new businesses with current assets \\
telecommunications engineer & - Role of content in service \\
9. Marketing and sales manager & - Changes in 5G technology \\
10. Radio access network engineer & - Increasing operational efficiency \\
\hline
\end{tabular}

developments that signal potential future change (emerging issues) in regulatory, technology, and business domains, given they are the most relevant domains to 5G market changes (Ahokangas et al., 2013). The time horizon was defined by the participants and is context-based. Selecting the viable time horizon is an important factor in applying foresight. It is based on the type of future under study, as well as the type of business, market, target group, and investment (Duin, 2006). Since the telecommunications industry is rapidly changing, three years ahead was considered feasible and logical to envision and plan.

"Visioning" as a strategic foresight method entails setting goals and creating a direction to the future to which the firm can commit. Visioning helps with strategic planning for the future by ensuring that goals are driven by the organisation's values and that stakeholders are participating (Bezold, 2009). Visions created during the 'visioning' process are products of stakeholder dialogues, for instance, when analysing and understanding problems and possible solutions to respond to potentially undesirable contextual changes. Visioning helps to successfully converge actions in a desired direction (van der Helm, 2009).

The author applied visioning to activate workshop participants' futures thinking, to help define clear objectives and a well-organized strategy, and to craft and deliver a shared actionable vision of innovative and future-oriented business models for 5G networks. Hence, visioning helped to reduce the uncertainty of the BMI process and thereby sought to improve company performance and competitive advantage.

\section{Summary of Analysis and Results}

\section{Shaping a future-oriented BMI process by applying horizon scanning and visioning}

This section presents the results of integrating BMI process and strategic foresight methods. For the BMI process, I adopted the framework suggested by Wirtz and Daiser (2018) made of analysis, ideation, feasibility, and prototyping. The case company took over implementing the business models separately, which was beyond the scope of the workshops. For business model representation (Figure 3), I applied the magic triangle model developed by Gassmann et al. (2014). The framework addresses four major areas including, 1) the target customer, 2) the customer value proposition, 3) the value chain behind the creation of the value, and 4) the revenue model that captures value. Figure 2 exhibits the business model innovation process and activities that were performed throughout the process.

Step 1: Assessing the current business model

The analysis phase of the BMI process addresses the current business model from a content perspective through scanning and scoping the current situation, as 


\section{Visioning Business Model Innovation for Emerging 5G Mobile Communications Networks Sara Moqaddamerad}

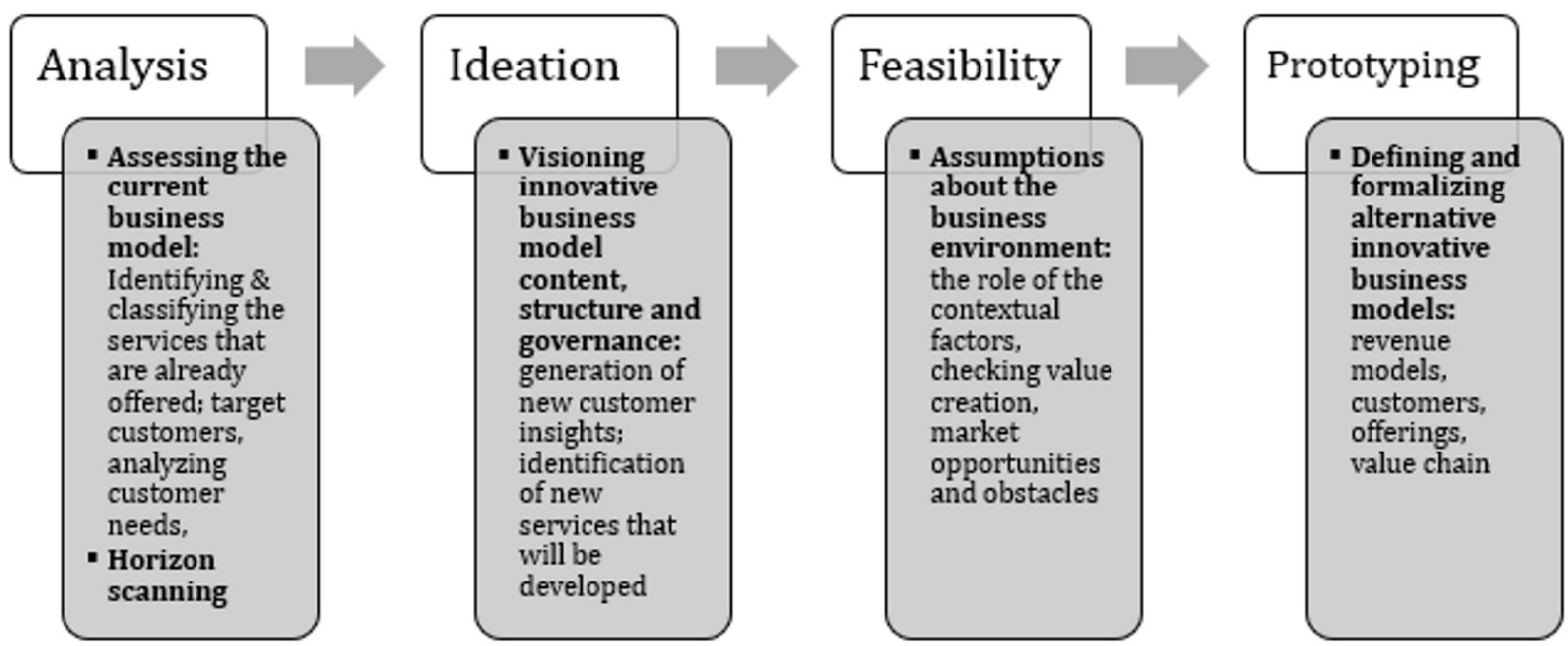

Figure 2. Business model innovation process and related activities combined with strategic foresight methods. Adopted and modified from Wirtz and Daiser (2018)

well as understanding the current business model weaknesses, strengths, opportunities and threats. As illustrated in Figure 3, currently MNOs form the main and the most important customers for the case company. MNOs generate $95 \%$ of the company's revenue through annual agreements and account for traditional daily services related to the company's core competencies in communication and infrastructure

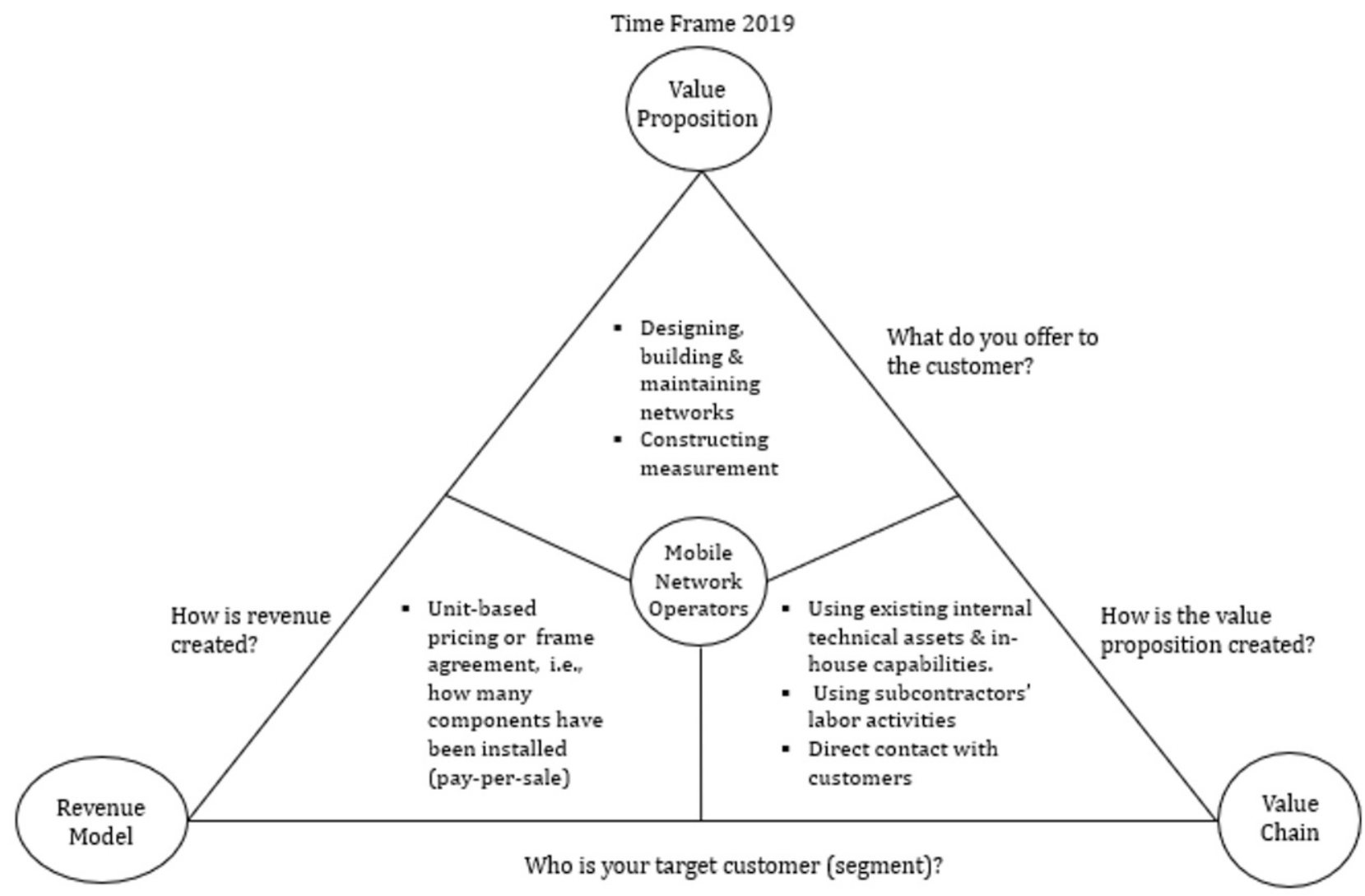

Figure 3. Current business model (2019) 


\section{Visioning Business Model Innovation for Emerging 5G Mobile Communications Networks Sara Moqaddamerad}

Table 2. Horizon scanning

\begin{tabular}{|c|c|c|}
\hline \multicolumn{3}{|c|}{ Trends in the Telecommunications Industry } \\
\hline Technology & Business & Regulatory \\
\hline $\begin{array}{l}\text { 1. Change in network } \\
\text { deployment from } \\
\text { outdoor local cell to } \\
\text { indoor local small cell } \\
\text { networks. } \\
\text { 2. Softwarization and } \\
\text { virtualization of mobile } \\
\text { networks. } \\
\text { 3. Increasing use of AI in } \\
\text { network management } \\
\text { and optimization. } \\
\text { 4. Increasing use of } \\
\text { higher frequency bands } \\
\text { for indoors coverage. }\end{array}$ & $\begin{array}{l}\text { 1. The growth of local service } \\
\text { demand in the digitalization } \\
\text { of different verticals } \\
\text { (factories, campuses, etc.) } \\
\text { especially indoors. } \\
\text { 2. Growing need for local } \\
\text { indoor small cell networks } \\
\text { and spectrum licenses. } \\
\text { 3. Cost-efficient network } \\
\text { scaling according to demand } \\
\text { through sharing, i.e. } \\
\text { "Network-as-a-Service". } \\
\text { 4. Change in network } \\
\text { deployment from owning } \\
\text { infrastructure to buying } \\
\text { required infrastructure as a } \\
\text { service. } \\
\text { 5. Entrance of new } \\
\text { stakeholders to mobile } \\
\text { communications market. }\end{array}$ & $\begin{array}{l}\text { 1. Change in network } \\
\text { deployment from a small } \\
\text { number of nation-wide long- } \\
\text { term spectrum licenses to a } \\
\text { larger number of sharing- } \\
\text { based local spectrum licenses. } \\
\text { 2. Change in network } \\
\text { deployment from a small } \\
\text { number of dominant MNOs to } \\
\text { the emergence of a larger } \\
\text { number of local operators. } \\
\text { 3. Defining new regulations } \\
\text { for spectrum sharing, e.g. local } \\
\text { licensing. }\end{array}$ \\
\hline
\end{tabular}

management (designing, planning, building, and maintaining networks). The revenue model is task/activity-based or time/unit-based, with the highest revenue achieved through pure installation work. The company's strengths revolve around its strong expertise and skills in this field that can pave the way for finding new opportunities (new customer segments and offerings).

The emergence of $5 \mathrm{G}$ technology has especially created a lot of uncertainty and turbulence in the market as new local operators enter the market. Thus, it has become important to understand this new technology and grasp how it might influence the company's operational effectiveness and performance. For that, they need to monitor trends in the industry to effectively renew their business models. The next activity in the process addresses this issue through horizon scanning.

\section{Horizon scanning}

New business models are often based on early signals of change, for instance, new technologies, new customer requirements, or new regulations (Gassmann et al., 2014). Horizon scanning (Table 2) as a creative activity helps participants to think differently, both by identifying trends that will form the most likely future and by pinpointing threats and opportunities. This activity enables anticipating and accommodating opportunities. In this study, the questions asked were, "what are the most influential trends in the telecommunications industry? And how will they affect the case company?"

An analysis of insights from these trends indicates that the company's environment is substantially changing. For instance, spectrum bands (from $3.5 \mathrm{GHz}$ and higher) will soon be available for different service provisioning, which require radio access permission from regulators for operating services. The company now faces uncertainty from various technologies (for example, LTE, 5G, WLAN) being developed in their desired direction. Additionally, the current way of offering services and generating revenue will likely no longer be profitable with the advent of $5 \mathrm{G}$ networks, since mobile operators have started moving towards easier installation of hardware and software in a way that everything can be installed remotely, controlled, and operated through cloud-based services.

Telecommunications services will be mostly offered for indoor purposes, while many new entrants are now entering the market and could impact the value chain 


\section{Visioning Business Model Innovation for Emerging 5G Mobile Communications Networks Sara Moqaddamerad}

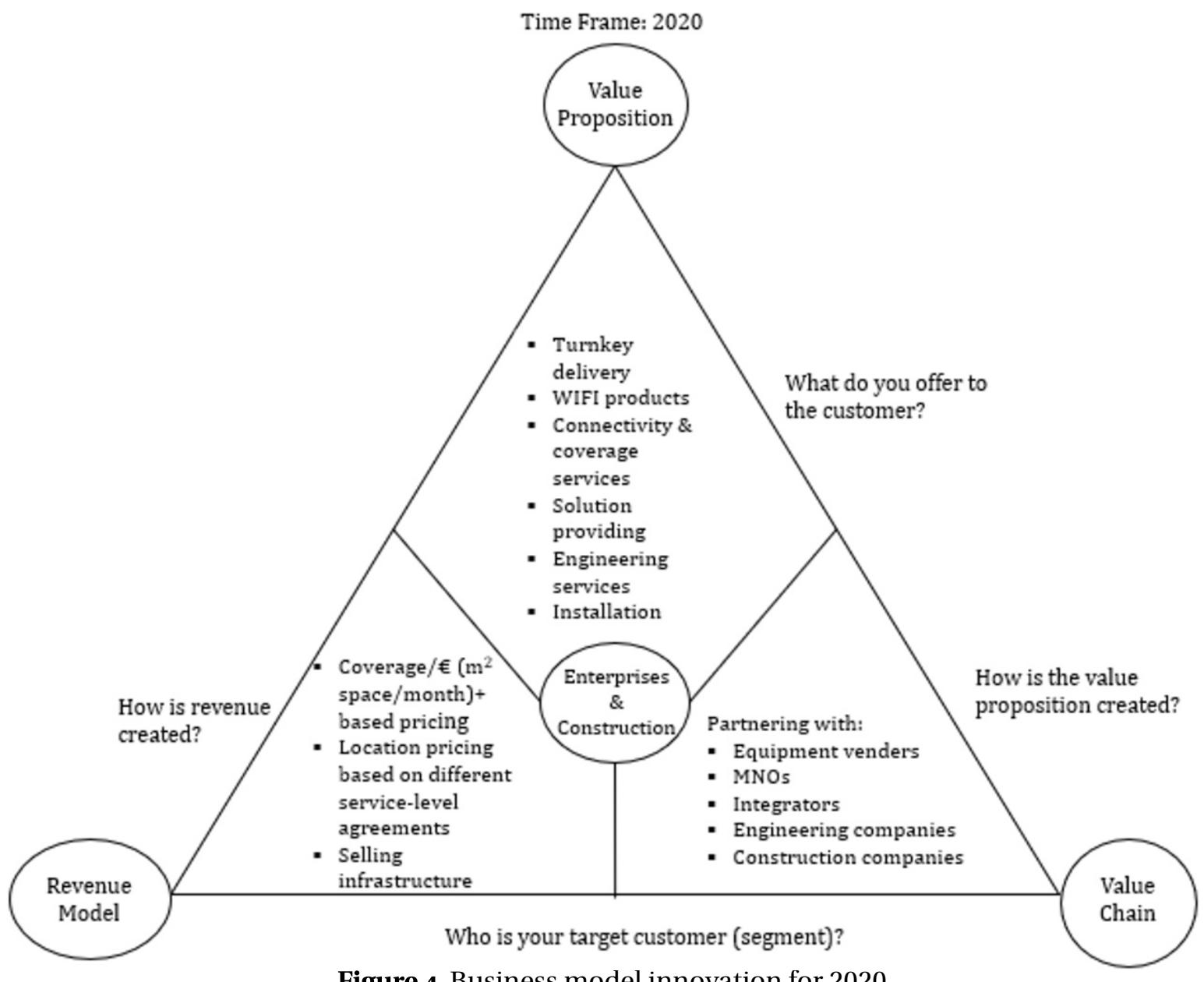

Figure 4. Business model innovation for 2020

and value network activities. These changes necessitate the case company to acquire new skills and enhance its competency in service and data provisioning, as well as operational excellence, renew its organizational structure and respond to end customer needs, and change the governance of its external resources and relationships. Achieving growth requires offering high quality indoor services (for example, connectivity and coverage) and in that sense, the company must compete with operators who have $90 \%$ share of indoor services. The case company has a major advantage over the operators in having built an existing high-quality network infrastructure. All in all, the case company needs to move fast, act proactively, learn from good practices, take more risks, and find its position within the value chain of high margin business. The next steps address possible solutions in the form of alternative innovative business models.

\section{Step 2: Ideation}

The ideation phase generates clear BMI ideas and concepts, as well as establishing the rationale, scope and key objectives of the new business model. While horizon scanning can be a key input to the visioning process, visioning activities can uncover the company's goals and aspirations, bringing consideration of the future back to the present, thereby creating the basis for BMI. As a researcher working with the case company, I began the visioning process by asking "where would the company like to be in 2022?" And "what are the areas for business model renewal until 2022?" The participants had to identify and prioritize areas of common grounds built on positive change in the company's current business model, as well as thinking about preferable future business models.

Step 3: Feasibility

Participants should be able to better sense the feasibility 


\section{Visioning Business Model Innovation for Emerging 5G Mobile Communications Networks Sara Moqaddamerad}

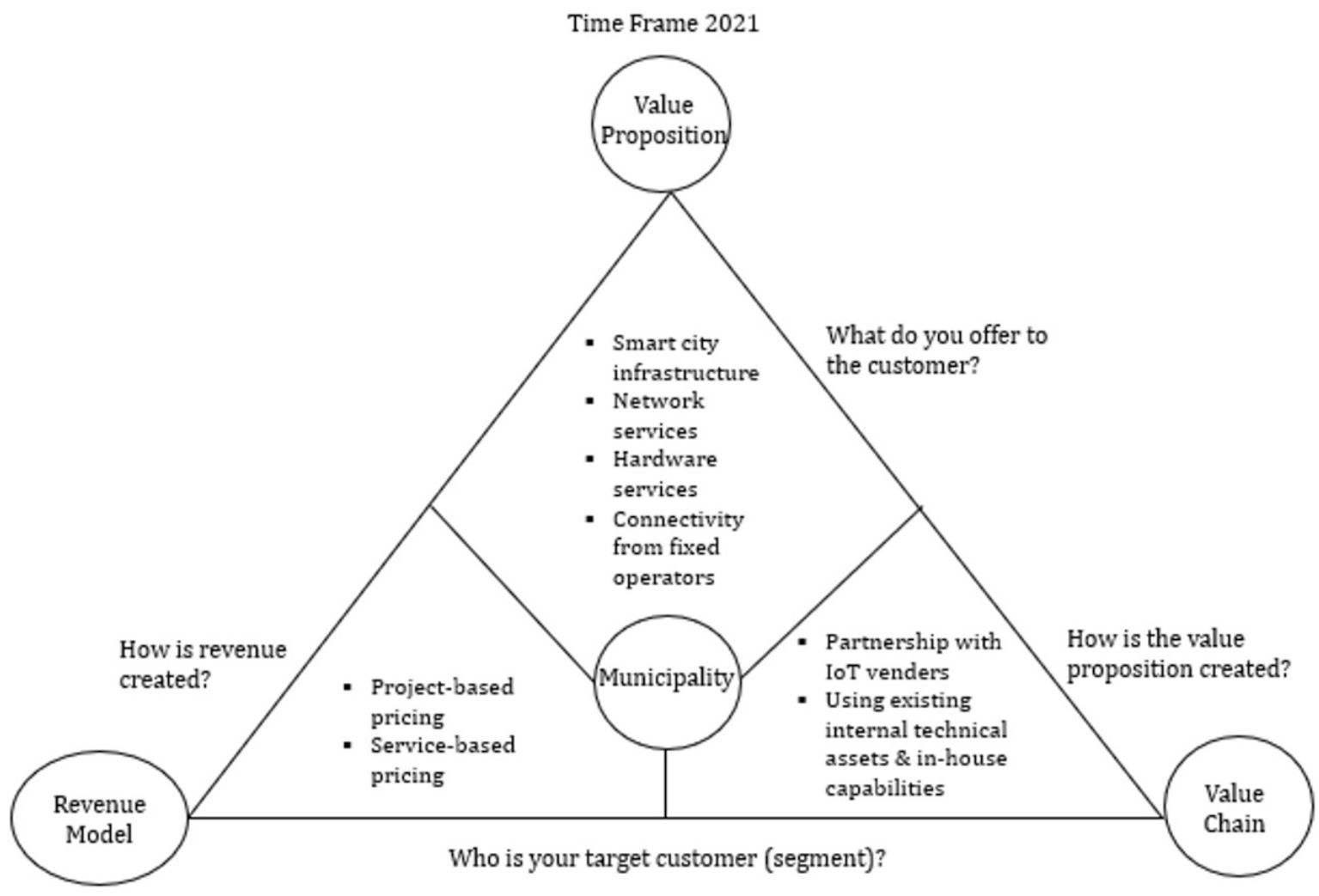

Figure 5. Business model innovation for 2021

of new business models (that is, evaluating the practicality and impact of the conceptual draft of BMI) by scanning the environment, finding technology requirements, analysing the market, industry and competition.

\section{Step 4: Prototyping}

After confirming the feasibility of a BMI, the content of an alternative business model is prototyped, evaluated, refined, and optimized. In practice, these three steps happened together through questioning and extensive discussions between the participants during the workshops. Based on this activity, three different innovative business models were developed looking ahead to 2022 (see Figures 4, 5, \& 6).

\section{Business model innovation on the horizon}

The participants created three innovative business models based on value creation and capture ideas and opportunities, as well as targeting customers that they had identified through previous steps. Figure 4 displays the business model innovation for 2020 .

In the 2020 business model, the target customers were enterprises and construction companies (building houses, shopping malls, factories, industrial automation) and their customers included real estate companies, property management organizations, renovation companies, and end users. Construction companies are the channels for reaching enterprises. Construction companies, however, are not specialized in managing operations inside buildings and therefore cannot maintain continuous services. This creates a new opportunity for the case company to create and capture value.

In this situation, 5G networks have not yet been commercialized. The case company can therefore offer high quality WIFI services apart from infrastructure services and quality management services, both for MNOs and enterprises. These services can be offered through subcontractors and may lead to additional projects. The case company may also act as an integrator and distribute or sell big vendors' equipment. Nevertheless, moving towards offering engineering solutions appears to be more promising now as we approach the onset of 5G networks. The company believes that partnering with vendors will create more 


\section{Visioning Business Model Innovation for Emerging 5G Mobile Communications Networks Sara Moqaddamerad}

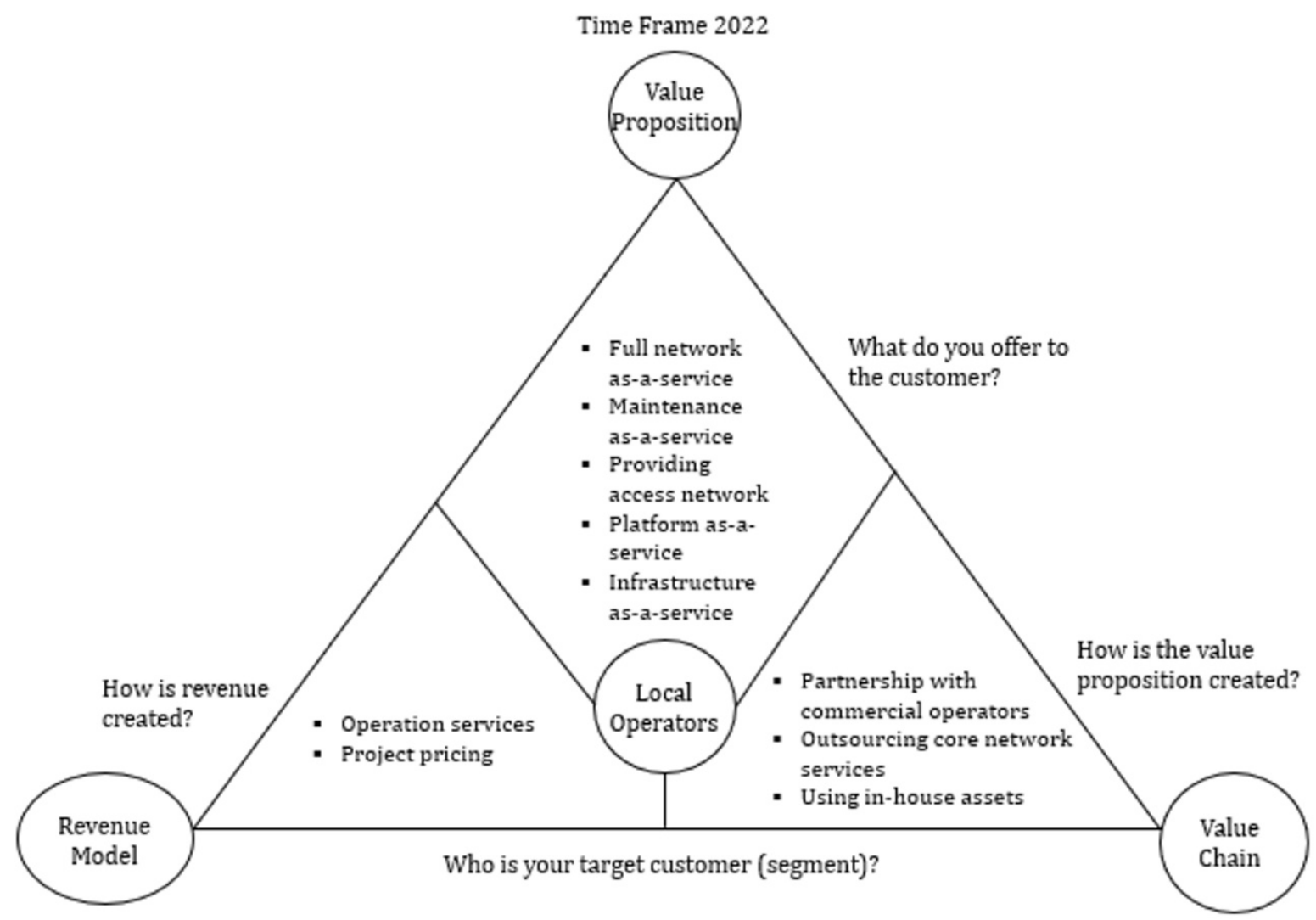

Figure 6. Business model innovation for 2022

opportunities for offering their network-as-a-service indoors. In this regard, MNOs become strategic partners to the case company because of their network of customers and the services needed from the case company (that is, building infrastructure). Revenue will be mainly generated through leasing, monetizing coverage, connectivity (based on existing locations), and site acquisition, as well as selling infrastructure and installation payments.

The next year's business model (2021), Figure 5, focuses on a new customer, that is, a municipality. In this situation, the company aims to enable "smart city" operation by offering services like the design and utilization of IoT, infrastructure, hardware, and improved connectivity. The company's value chain functions through partnering and integrating with IoT venders, while the revenue model is project- and service-based pricing.

As a result of the interviews and workshop, it is recommended that the company combine its experience and expertise in telecom and electricity to provide services to the municipality when constructing different areas and blocks. It should thus move towards partnering with IT companies to create more value for end customers and expand its market share.

The business model innovation for 2022, as shown in Figure 6, serves a new customer segment, i.e. local operators. In this situation, $5 \mathrm{G}$ networks are assumed to be ready for commercial purposes. Local operators can include hospitals, campuses, utilities, factories, shopping malls, sport arenas, and others, which may need to have a wide variety of infrastructure and network services, such as accessing the core network, connectivity, and maintaining the whole ICT infrastructure.

In this situation, the company can gain the advantage of offering a whole package for infrastructure and platform as-a-service, as well as securing connectivity service contracts for all customers. Acting as a local operator would require having cloud capabilities, a core network (hosted by Google), and an access network that MNOs and vendors sell to. The case company should therefore outsource its core network as-a-service. Getting into indoor services offering business requires cooperation 


\section{Visioning Business Model Innovation for Emerging 5G Mobile Communications Networks Sara Moqaddamerad}

with commercial operators, since they have an existing network of customers. Hence, business models for the 5G era are shaped around local operators as customers and partnering with commercial operators to create value. Since the largest share of the company's market is within northern Europe, revenues there would be high while competition would be limited. Moreover, one novel opportunity could be starting with a "Wi-Fi network lighting" to get into the $5 \mathrm{G}$ market outside of traditional telco operators. The participants understood the importance of creating these visionary business models both for customizing and packetizing the service offerings and classifying customer approaches in practice.

\section{Discussion}

The innovative business models envisioned above with a strategic lens aim at creating new internal and external (interdependent) activities that can be governed in a way that creatively link value creation to value capture. This reflects a novel view of strategy development in which strategic choices are able to focus on designing effective interdependent activities (Lanzolla \& Markides, 2020). Identifying existing trends and key uncertainties can significantly affect the industry and the company's future. This not only enables anticipating and accommodating opportunities, but also insight to provide inputs towards creating new visions and discovering their possible business outcomes. During the BMI process, the case company's strategies got built on a shared vision of the most important features of their future business models, which identified potential customers and gained understanding of their needs.

Factors like an industry's background and structure, a company's core capability, or the diverse strategic segments in which the company competes, together with considering uncertainties about the future (Schoemaker, 1992) are addressed during the visioning process. These factors are crucial for generating strategic visions. BMI in this way becomes key to the heart of a firm's strategic vision. The research findings highlight the company's core capabilities (engineering, product/service quality, quality of personnel) can be effective for multiple strategic market segments that they might be competing in (market segmentation, service groupings, technology), with the aid of future-oriented innovative business models. These core capabilities seemed to be durable and form the ground for the company's sustainable competitive advantage.
However, the case company under study in this research paper also realized that it must develop further their sales, marketing, and R\&D capabilities, along with its engineering capability and high-quality services.

By utilizing a process called "visioning" in a workshop setting, I intended to inspire and frame the participants' dialogue, open their mindset towards discussion about future developments incoming as a result of the emerging 5G market, and help evaluate potential actions. Visioning in this way helped understand the shape of the past and present, and enabled a productive map of the company's mental image of possible alternative strategy development (Van der Helm, 2009). This was done in a way that enacted collective sensemaking (perceiving, interpreting, and responding to change) and created "foresightful" knowledge (Sarpong \& Maclean, 2012). Being engaged in a temporal process focused on innovation, the participants actively constructed dynamic images of future business models and concentrated their efforts on developing a broad and shared outline of the innovative business models. This resulted in enhancing the company's learning capability, as well as awareness of the diverse set of emerging possible business futures. Thus, it helped lead to improved decision-making and implementation of strategies, according to the feedback after the interviews and workshop.

The practice of "horizon scanning" enabled the company's participants in developing BMI to build mental models that enabled them to better understand their business environment. By linking both visioning and time horizons, this helped them construct mental models for setting goals. Creating two or three (BMI) visions sequenced along a time continuum, so the theory goes, can help structure a company's future goals in clear achievable steps (Hines \& Bishop, 2013). The envisioned innovative business models enable the company to gain lead time for generating and/or directing change, along with greater flexibly to enact various activity systems, and allocate resources more efficiently. Moreover, in the face of exogenous shocks, old ways of thinking and ad hoc created business models cannot offer to provide sustained realistic growth into the future. In that case, innovations must emerge through revitalized ways of thinking and strategic foresight, which "visioning" in particular was designed to do. Indeed, if a company lacks strategic foresight, their business models often lack genuine novelty, agility and resilience, and consequently cannot adapt to and 


\section{Visioning Business Model Innovation for Emerging 5G Mobile Communications Networks Sara Moqaddamerad}

survive from exogenous shocks. Considering these benefits, the research from this study suggests it is worth integrating strategic foresight into a company's current processes of developing BMI.

\section{Conclusion}

This research attempted to apply strategic foresight approach for developing BMI in high velocity environments in order to help companies not to miss valuable uses of innovative technologies. The above report has shown that BMI can be an effective way for companies to manage the challenges of adopting disruptive technologies and increasing competition from the entry of disruptors. Innovative business models can generate substantial market value either by creating new markets or transforming existing ones. Moreover, innovative business models can become a crucial factor for a company's effectiveness in creating and capturing value in VUCA environments. Nevertheless, methods that can simplify and help business leaders understand such environments are scarce in the literature (Gibson, 2014). BMI regardless still requires both creativity and "structured guidance to frame and focus thought" (Eppler et al., 2011).

To address these issues, this study employed a qualitative single case study approach to integrate the concepts of BMI and strategic foresight (in terms of innovative future-oriented methods). This was done to capture the lived experiences of bottom-up ideation, as well to access and exploit the distributed expertise of business managers and engineers.

This study sought to contribute to our understanding on how strategic foresight methods can be systematically integrated in a BMI process in the context of the telecommunications industry, which is a dynamically changing complex of technologies and markets globally. The pragmatic value of "strategic foresight" has remained little understood by practicing managers, especially how it may help them to systematically innovate their business models. This study therefore tried to fill this gap by showing how strategic foresight can enable prospective and creative thinking, while improving the knowledge creation needed for solving problems. This approach to BMI can give managers a strong incentive to utilize strategic foresight methods regularly, as well as integrating them as ongoing daily practices for more effective BMI processes. The ability to demonstrate how future-oriented BMI can be managed in practice may lead to enhancing the development of
BMI theories. Likewise, it may help move towards unifying the strategic foresight and BMI research streams, which empirical evidence has so far been unable to support.

\section{References}

Afuah, A. \& Tucci, C.L. 2001. Internet business models and strategies: Text and cases. New York: McGrawHill.

https://www.researchgate.net/publication/21591516 3

Afuah, A. 2014. Business model innovation: concepts, analysis, and cases. Routledge.

Ahokangas, P. Matinmikko, M. Yrjola, S. Okkonen, H. \& Casey, T. 2013. " Simple Rules" For Mobile Network Operators' Strategic Choices in Future Cognitive Spectrum Sharing Networks. IEEE Wireless Communications, 20(2): 20-26.

DOI: 10.1109/MWC.2013.6507390

Amit, R. \& Zott, C. 2001. Value creation in e-business. Strategic management journal, 22(6 7): 493-520. https://doi.org/10.1002/smj.187

Amit, R. \& Zott, C. 2010. Business Model Innovation: Creating Value in Times of Change. http://dx.doi.org/10.2139/ssrn.1701660

Amit, R. \& Zott, C. 2012. Creating Value Through Business Model Innovation. MIT Sloan Management Review, 53(1): 40-49.

Bezold, C. 2009. Aspirational Futures. Journal of Futures Studies, 13(4): 81-90.

Bucherer, E., Eisert, U. \& Gassmann, O. 2012. Towards Systematic Business Model Innovation: Lessons from Product Innovation Management. Creativity and innovation management, 21(2): 183-198. https://doi.org/10.1111/j.1467-8691.2012.00637

Casadesus-Masanell, R. \& Ricart, J.E. 2010. From strategy to business models and onto tactics. Long range planning, 43(2-3):195-215. https://doi.org/10.1016/j.lrp.2010.01.004

Casadesus-Masanell, R. \& Zhu, F. 2013. Business Model Innovation and Competitive Imitation: The Case of Sponsor Based Business Models. Strategic management journal, 34(4): 464-482. https://doi.org/10.1002/smj.2022

Chesbrough, H. \& Rosenbloom, R.S. 2002. The role of the business model in capturing value from innovation: evidence from Xerox Corporation's technology spin-off companies. Industrial and corporate change, 11(3): 529-555. https://doi.org/10.1093/icc/11.3.529

Chesbrough, H. 2010. Business Model Innovation: Opportunities and Barriers. Long Range Planning, 43(2-3): 354-363.

https://doi.org/10.1016/j.lrp.2009.07.010 


\section{Visioning Business Model Innovation for Emerging 5G Mobile Communications Networks Sara Moqaddamerad}

Courtney, H. 2001. 20/20 Foresight: Crafting strategy in an uncertain world. Harvard Business Press.

Day, G.S. \& Schoemaker, P.J. 2005. Scanning the Periphery. Harvard business review, 83(11): 135.

Demil, B. \& Lecocq, X. 2010. Business Model Evolution: In Search of Dynamic Consistency. Long Range Planning, 43(2-3): 227-246.

https://doi.org/10.1016/j.lrp.2010.02.004

Duin, P.A. 2006. Qualitative futures research for innovation. Eburon Uitgeverij BV.

Eppler, M.J. \& Hoffmann, F. 2012. Does Method Matter? An Experiment on Collaborative Business Model Idea Generation in Teams. Innovation, 14(3): 388-403. https://doi.org/10.5172/impp.2012.14.3.388

Foss, N.J. \& Saebi, T. 2017. Fifteen Years Of Research On Business Model Innovation: How Far Have We Come, And Where Should We Go?. Journal of Management, 43(1): 200-227.

https://doi.org/10.1177/0149206316675927

Gassmann, O., Frankenberger, K. \& Csik, M. 2014. The business model navigator: 55 models that will revolutionise your business. Pearson UK.

Gibson, E. \& Jetter, A. 2014. Towards A Dynamic Process for Business Model Innovation: A Review of the Stateof-the-Art. In: Proceedings of PICMET'14 Conference: Portland International Center for Management of Engineering and Technology; Infrastructure and Service Integration, IEEE: 1230-1238.

Girotra, K. \& Netessine, S. 2014. Four paths to business model innovation. Harvard business review, 92(7): 96103.

Hines, A. \& Bishop, P.J. eds. 2013. Thinking about the future: Guidelines for strategic foresight. Washington, DC: Social Technologies.

Horton, A. 1999. A Simple Guide to Successful Foresight. Foresight - The journal of future studies, strategic thinking and policy, 1(1): 5-9.

Karp, T. 2004. Building Foresight Abilities in Organizations: A Future Opportunity for Futures Studies. Futures Research Quarterly, 20: 5-30.

Kindström, D. \& Kowalkowski, C. 2015. Service Driven Business Model Innovation: Organizing the Shift from A Product-Based to A Service-Centric Business Model. In: Business Model Innovation: The Organizational Dimension, Nicolai Foss and Tina Saebi (Eds.), Oxford University Press.

Lanzolla, G. \& Markides, C. 2020. A Business Model View of Strategy. Journal of Management Studies. https://doi.org/10.1111/joms.12580

Lemos, A.D. \& Porto, A.C. 1998. Technological forecasting techniques and competitive intelligence: tools for improving the innovation process. Industrial Management \& Data Systems.

https://doi.org/10.1108/02635579810227698

Matinmikko, M., Latva-Aho, M., Ahokangas, P., Yrjölä, S. \& Koivumäki, T. 2017. Micro Operators to Boost Local

timreview.ca
Service Delivery in 5G. Wireless Personal Communications, 95(1): 69-82.

https://doi.org/10.1007/s11277-017-4427-5

Massa, L., Tucci, C.L. \& Afuah, A. 2017. A critical assessment of business model research. Academy of Management Annals, 11(1): 73-104.

https://doi.org/10.5465/annals.2014.0072

Mitra, R.N. \& Agrawal, D.P. 2015. 5G mobile technology: A survey. ICT Express, 1(3): 132-137.

https://doi.org/10.1016/j.icte.2016.01.003

Moqaddamerad, S., Ahokangas, P., Matinmikko, M. \& Rohrbeck, R. 2017. Using scenario-based Business Modelling to Explore The 5G Telecommunication Market. Journal of Futures Studies, 22(1): 1-18.

DOI: 10.6531/JFS.2017.22(1).A1

Cortimiglia, M.N., Ghezzi, A. \& Frank, A.G. 2015. Business Model Innovation and Strategy Making Nexus: Evidence from A Cross Industry Mixed Methods Study. R\&D Management, 46(3): 414-432.

https://doi.org/10.1111/radm.12113

Osterwalder, A., Pigneur, Y. \& Tucci, C.L. 2005. Clarifying Business Models: Origins, Present, and Future of the Concept. Communications of the Association for Information Systems, 16(1): 1-25.

Porter, M.E. 1996. What is strategy? Harvard business review, 74(6): 61-78.

Porter ME. \& Gibbs, M. 2001 Strategy and The Internet. Harvard Business Review, 79(3): 63-78.

Rasmussen, B., Andersen, P.D. \& Borch, K. 2010. Managing transdisciplinarity in strategic foresight. Creativity and Innovation Management, 19(1): 37-46. https://doi.org/10.1111/j.1467-8691.2009.00534.x

Richardson, J.E. 2005. The business model: an integrative framework for strategy execution. http://dx.doi.org/10.2139/ssrn.932998

Rohrbeck, R., Battistella, C. and Huizingh, E., 2015. Corporate Foresight: An Emerging Field with a Rich Tradition. Technological Forecasting and Social Change, 101: 1-9.

Sarpong, D. \& Maclean, M. 2012. Mobilising differential visions for new product innovation. Technovation, 32(12): 694-702.

Sarpong, D. \& Maclean, M. 2016. Cultivating Strategic Foresight in Practise: A Relational Perspective. Journal of Business Research, 69(8): 2812-2820.

Schaller, A.A., Vatananan-Thesenvitz, R. \& Stefania, M. 2018. Business Model Innovation Roadmapping: A Structured Approach to A New Business Model. In: 2018 Portland International Conference on Management of Engineering and Technology (PICMET), IEEE: 1-9.

DOI: 10.23919/PICMET.2018.8481976

Schneider, S. \& Spieth, P. 2013. Business Model Innovation: Towards an Integrated Future Research Agenda. International Journal of Innovation 


\section{Visioning Business Model Innovation for Emerging 5G Mobile Communications Networks Sara Moqaddamerad}

\author{
Management, 17(01): 1340001-34. \\ https://doi.org/10.1142/S136391961340001X
}

Schoemaker, P.J. 1992. How to Link Strategic Vision to Core Capabilities. Sloan Management Review, 34: 6767.

Schwarz, J.S. \& Legner, C. 2020. Business model tools at the boundary: exploring communities of practice and knowledge boundaries in business model innovation. Electronic Markets, 30: 1-25.

https://doi.org/10.1007/s12525-019-00379-2

Tesch, J. \& Brillinger, A. 2017. The Evaluation Aspect of Digital Business Model Innovation: A Literature Review on Tools and Methodologies. In: Proceedings of the 25th European Conference on Information Systems (ECIS), Guimarães, Portugal, June 5-10, 2017: 2250-2268.

http://aisel.aisnet.org/ecis2017_rp/143

Teece, D.J. 2007. Explicating Dynamic Capabilities: The Nature and Microfoundations of (Sustainable) Enterprise Performance. Strategic management journal, 28(13): 1319-1350. https://doi.org/10.1002/smj.640

Teece, D.J. 2010. Business models, business strategy and innovation. Long range planning, 43(2-3): 172-194. https://doi.org/10.1016/j.lrp.2009.07.003

Tesch, J.F. 2016. Discovering the role of scenario planning as an evaluation methodology for business models in the era of the internet of things (IoT). In: the ECIS 2016 Proceedings at AIS Electronic Library (AISeL).

http://aisel.aisnet.org/ecis2016_rp/175

Van der Helm, R. 2009. The vision phenomenon: Towards a Theoretical Underpinning of Visions of the Future and the Process of Envisioning. Futures, 41(2): 96-104.

https://doi.org/10.1016/j.futures.2008.07.036

Vecchiato, R. 2012a. Environmental Uncertainty, Foresight and Strategic Decision Making: An Integrated Study. Technological Forecasting and Social Change, 79(3): 436-447.

https://doi.org/10.1016/j.techfore.2011.07.010

Vecchiato, R. 2012b. Strategic Foresight: Matching Environmental Uncertainty. Technology Analysis \& Strategic Management, 24(8): 783-796.

https://doi.org/10.1080/09537325.2012.715487

Verganti, R. \& Shani, A.B.R. 2016. Vision Transformation Through Radical Circles: Enhancing Innovation Capability Development. Organizational Dynamics, 45: 104-113.

http://hdl.handle.net/11311/1020130

Wieland, H. Hartmann, N.N. \& Vargo, S.L. 2017. Business Models as Service Strategy. Journal of the Academy of Marketing Science, 45(6): 925-943.

DOI: $10.1007 / \mathrm{s} 11747-017-0531-\mathrm{z}$

Wirtz, B.W., Schilke, O. and Ullrich, S. 2010. Strategic Development of Business Models: Implications of
The Web 2.0 For Creating Value on the Internet. Long range planning, 43(2-3): 272-290.

Wirtz, B.W., Pistoia, A., Ullrich, S. \& Göttel, V. 2016. Business Models: Origin, Development and Future Research Perspectives. Long range planning, 49(1): 36-54.

https://doi.org/10.1016/j.lrp.2015.04.001

Wirtz, B. and Daiser, P. 2018. Business Model Innovation Processes: A Systematic Literature Review. Journal of Business Models, 6(1): 40-58. https://doi.org/10.5278/ojs.jbm.v6i1.2397

Yin, R.K. 2018. Case study research and applications: Design and methods. Sixth edition, Sage publications.

Zott, C. \& Amit, R. 2010. Business Model Design: An Activity System Perspective. Long Range Planning, 43(2-3): 216-226.

https://doi.org/10.1016/j.lrp.2009.07.004

Zott, C., Amit, R. \& Massa, L. 2011. The Business Model: Recent Developments \& Future Research. Journal of Management, 37(4): 1019-1042.

https://doi.org/10.1177/0149206311406265

\section{About the Author}

Sara Moqaddamerad is doctoral candidate in management and organization at University of Oulu and project researcher at Martti Ahtisaari Institute affiliated to Oulu Business School. With a background in Futures Studies, Ms. Moqaddamerad is enthusiastic about developing the practice of strategic foresight in organizations and industries, especially in strategic management and business model innovation fields. Ms. Moqaddamerad has been working on a wide variety of technology contexts including 5G, IoT, smart grids, smart cities, AI, Fintech and healthcare. Ms. Moqaddamerad has practiced different foresight techniques for developing innovative business models for different technologies, especially $5 \mathrm{G}$ networks and has been teaching scenario planning, coordinating entrepreneurship minor studies, as well as designing an online course for blockchain technology.

Citation: Moqaddamerad, S. 2020. Visioning Business Model Innovation for Emerging $5 \mathrm{G}$ Mobile Communications Networks. Technology Innovation Management Review, 10(12): 4-18. http://doi.org/10.22215/timreview/1406

(cc) BY

Keywords: Business model, business model innovation, strategy, strategic foresight, visioning, 5G technology 